\title{
СУСПІЛЬНИЙ ЗАПИТ І ПІДТРИМКА ПРОФЕСІЙНОГО РОЗВИТКУ ВЧИТЕЛЯ В АВСТРАЛІЇ
}

Костіна Л. С. Суспільний запит і підтримка професійного розвитку вчителя в Австралії.

У статті розглянуто соціальний контекст професійного розвитку вчителів середніх шкіл в Австралії. Визначено цілі й шляхи державної підтримки вчителів й державні вимоги до професійного навчання вчителів. Проаналізована роль і діяльність професійних освітніх асоціацій Австралії в професійному становленні вчителя.

Ключові слова: професійний розвиток, суспільний запит, державна підтримка, професійні освітні асоціації.

Костина Л. С. Общественный запрос и поддержка профессионального развития учителя в Австралии.

В статье рассмотрен социальный контекст профессионального развития учителя средних школ в Австралии. Определены цели и пути государственной поддержки и требований к профессиональному обучению учителей. Проанализирована роль и деятельность профессиональных образовательных ассоциаций Австралии в профессиональном становлении учителя.

Ключевые слова: профессиональное развитие, общественный запрос, государственная поддержка, профессиональные образовательные ассоциации.

Kostina L. S. Social demand and support for teacher professional development in Australia.

Social context of teacher professional development in Australian secondary schools is considered in the article. Main goals and directions of state support and demand for teacher professional learning are determined. The role and activities of Australian professional learning associations in teacher professional development is analyzed.

Key words: professional development, social demand, state support, professional learning associations.

Концепція професійного розвитку вчителів у школі як навчальної організації або ефективного навчального середовища набуває все більшої популярності в галузі освіти Австралії. У свою чергу, учитель детермінується як частина професійного навчального співтовариства 3 високим рівнем колаборації, когерентної діяльності, пов'язаної 3 професійним розвитком, і спільної навчальної практики. Якісна діяльність учителя є одним із найважливіших показників учнівської успішності. Лінда Дарлінг-Хеммонд виражає це такими словами: «Учителі, які знають багато про викладання й навчання і працюють у середовищі, що уможливлює глибоке пізнання учнів, $\epsilon$ цінними елементами успішного навчання» $[5$, с. 12]. Якщо якісне навчання повинно відбуватися у класній кімнаті, необхідно забезпечити учителів всіма наявними умовами задля постійного професійного зростання.

Аналіз науково-педагогічної періодики Австралії, документів Міністерства освіти Австралії і професійних освітніх асоціацій надає підстави стверджувати, що якісна діяльність вчителя середніх шкіл $є$ одним із найважливіших показників учнівської успішності в Австралії. Отже, виникає потреба проаналізувати, у першу чергу, суспільний запит професійного розвитку вчителів, що складається 3 стандартів 
та вимог до якісного вчителя і державної підтримки, а також діяльність професійних асоціацій у професійному становленні учителя в Австралії.

Проблеми визначення адекватних шляхів професійного розвитку вчителів широко висвітлені у педагогічній зарубіжній літературі, зокрема в науковій періодиці Австралії, документації Міністерства освіти Австралії. Велика кількість австралійських дослідників і науковців присвятили свої праці аналізу й розв'язанню проблем професійного становлення вчителя середньої школи Австралії. Серед них К. Бурк, А. Вілсон, Н. Демпстер, С. Дінхем, Б. Дж. Келдвел, М. Ллойд, Х. Тімперлей та інші. Деякі дослідники займаються розробкою ефективної програми професійної діяльності й розвитку вчителя. Серед них А. Бертані, Б. Дженсен, Дж. Маршал, П. Сантьяго і інші.

Meта статmi - розкрити суспільний запит і підтримку професійного розвитку вчителя середніх шкіл в Австралії.

Відповідно до мети визначено такі завдання:

- розкрити державну підтримку і вимоги до професійного розвитку вчителя середніх шкіл в Австралії;

- проаналізувати роль професійних освітніх асоціацій Австралії у професійному становленні вчителя.

Аналізуючи суспільний запит і підтримку професійного розвитку вчителя Австралії, необхідно розглянути середовище, у якому відбувається постійний динамічний розвиток педагога-професіонала. В Австралії розмежовують дві загальні категорії школи: урядові й неурядові. Урядові школи підпорядковані уряду штату або території. Неурядові школи отримають додаткову фінансову підтримку від федерального уряду й уряду штату/території. Конституція Австралії наголошує на тому, що шкільна освіта (початкова й середня школи) підпорядкована безпосередньо штатам і територіям Австралії. Міністерство освіти, зайнятості й трудових відносин (Department of education, employment and workplace relations) прописує розподіл обов'язків так: у той час, як уряд Австралії відіграє провідну роль у просуванні освітніх реформ і гарантує фінансову підтримку зонам національної освітньої важливості, шкільна освіта в Австралії- це, переважно, конституційна відповідальність штатів і територій за управління і здійснення навчання у школі (програма навчання, акредитація курсу, оцінювання учнів і отримання кваліфікації тощо).

Характеристика середньої школи Австралії є неповною без профайлу вчителя середньої школи. Учитель викладає один або кілька предметів навчального курсу й забезпечує соціальний, емоційний, інтелектуальний i фізичний розвиток учня. Важливою деталлю для нашого дослідження є той факт, що 97 \% учителів Австралії мають універсальний доступ до можливостей професійного розвитку. Більшість учителів працюють у школах, де вони мають доступ до програм введення до спеціальності (induction programmes) i менторської підтримки. Окрім того, австралійські вчителі демонструють вищий за середній рівень залучення до різних видів діяльності, спрямованих на професійний розвиток.

Задля надання повного профайлу вчителя середньої школи слід зауважити, що цю посаду має право обіймати випускник зі ступенем бакалавра або вищою кваліфікацією. 3-поміж основних дескрипторів такої кваліфікації згідно Австралійської системи кваліфікацій (AQF) [2, с. 48] є володіння глибокими й когерентними знаннями, фундаментальними принципами і концепціями однієї або декількох дисциплін, що є основою для незалежного тривалого навчання; володіння когнітивними навичками для критичного розгляду, аналізу, консолідування й 
синтезування знань; володіє когнітивними й технічними навичками для демонстрації широкого розуміння знань з умінням фундаментального розгляду певних галузей; має когнітивні й креативні навички для критичного мислення та оцінки в незалежному інтелектуальному процесі визначення й розв'язання проблем; має комунікаційні навички задля чіткого, логічного й незалежного викладу знань і думок.

Суспільний запит професійного розвитку вчителя розкривається через державну i професійну підтримку вчителів. По-перше, слід розглянути державний запит і підтримку вчителів середньої школи. Доказом суспільного запиту професійного розвитку вчителя на всіх рівнях освітньої системи Австралії стало схвалення всіма міністрами освіти в 2012 році Австралійської програми 3 діяльності й розвитку вчителя (Australian Teacher Performance and Development Framework) i Австралійського уставу професійного навчання вчителів і шкільних лідерів (Australian Charter for the Professional Learning of Teachers and School Leaders) [7, с. 4].

Австралійська програма 3 діяльності й розвитку вчителя висвітлює вимоги до формування культури діяльності й розвитку вчителя в школах Австралії [3, с. 2]. Програма базується на Національних професійних стандартах для вчителів і створена для гарантії кар'єрної прогресії вчителів. Ядром програми є цикл діяльності й розвитку вчителя, компонентами якого виступають постановка цілей, професійна практика і навчання, викладення результатів та їх розгляд. Складниками культури діяльності й розвитку є чітке розуміння ефективності навчання, лідерство, гнучкість, когерентність і зосередження на учнівській успішності.

Державні вимоги до якості вчителів детально позначені в Австралійському уставі професійного навчання вчителів і шкільних лідерів. Професійне навчання розуміється як ефективний засіб розвитку індивідуальної і колективної здатностей у професії вчителя відповідати викликам теперішнього й майбутнього часів. Устав надає змогу зрозуміти головні характеристики професійного навчання: відповідність цілям, колаборативність і сфокусованість на майбутньому [1, с. 4].

Отже, австралійський уряд визнає себе лідером у підтримці професії вчителя й одночасно 3 іншими зацікавленими сторонами генерує i виховує винятково інноваційних учителів і шкільних лідерів Австралії. На підтвердження цього в грудні 2008 року були реалізовані Національні ініціативи стосовно освіти в Австралії, коли міністри освіти всіх штатів, територій і країн Британської Співдружності опублікували Мельбурнську Декларацію (Melbourne Declaration on Educational Goals for Young Australians). Декларація проголошує рівність і високу якість австралійської системи освіти. Досягнення мети декларації реалізується не тільки однією групою учасників навчального процесу, це $є$ «колективна відповідальність урядів, шкільних секторів і окремих шкіл, як і батьків, молодих австралійців, родин, провайдерів освіти й навчання, учителів, ділових й інших співтовариств тощо» [10, с. 3]. На додаток до Декларації міністри опублікували 4-річний план. План регламентує стратегії та ініціативи, спрямовані на реформування навчання вчителів на національному рівні 3 підтримкою штатів і територій і включає такі реформи:

1. Національні професійні стандарти для вчителів.

2. Національна система акредитації освітніх програм для вчителів-початківців.

3. Загальнонаціональний підхід до реєстрації вчителя.

4. Національний підхід до Сертифікації високорозвинутих вчителів і вчителівлідерів.

5. Потреби в професійному розвитку для директорів і шкільних лідерів.

6. Національні професійні стандарти для директорів.

7. Австралійський навчальний план [10, с. 4-5]. 
Задля реалізації реформи австралійський уряд започаткував Австралійський Інститут навчання і шкільного лідерства (Australian Institute for Teaching and School Leadership, AITSL). Головна мета AITSL - «забезпечити національне лідерство для уряду Співдружності, штатів і територій в сприянні високої якості професії вчителя і шкільного лідерства» [8, с. 73]. Згідно з Національною угодою про партнерство 3 підвищення якості вчителів (National Partnership Agreement on Improving Teacher Quality) всі штати і території домовилися розвивати і запроваджувати комплект національно узгоджених стандартів 32011 року, які фактично, надають платформу для реформування педагогічних працівників.

Зауважимо, що Національні професійні стандарти для вчителів детермінують роботу вчителів і деталізують елементи соціального контексту професійного розвитку вчителя 21 століття [9, с. 2-3]. Документ регламентує сім Стандартів, які окреслюють обсяг знань і можливостей учителів. Стандарти взаємопов'язані, взаємозалежні й частково збігаються. Стандарти згруповані відповідно до рівнів навчання: професійне знання (professional knowledge), професійна діяльність (professional practice) i професійне залучення (professional; engagement). Акцентовані зони поділені на дескриптори на чотирьох стадіях професійної кар'єри: випускник (Graduate), фахівець (Proficient), висококваліфікований фахівець (Highly Accomplished) i провідний фахівець (Lead).

Маючи за мету визначити основні цілі та принципи оцінювання фахівців, AITSL розробив документ під назвою «Сертифікація висококваліфікованого і провідного фахівців в Австралії» (Certification of Highly Accomplished and Lead Teachers in Australia). Сертифікація, як оцінювання, відбувається на основі Стандартів; сфокусована на учнівських досягненнях (визнає тих учителів, які виявили високу ефективність у покращенні учнівської успішності); $\epsilon$ частиною більш широкого підходу до кар'єрного розвитку, що включає професійне навчання, оцінювання діяльності і розвитку; $\epsilon$ достовірною за умови скрупульозних, обгрунтованих, надійних, чесних і прозорих засобів і процесів оцінювання діяльності вчителя. Крім того, Сертифікація, як дієвий стимул професійного зростання вчителя, повинна засновуватися на найкращих національних i міжнародних практиках i сприяти розробці дієвих шляхів досягнення якісного навчання [4, с. 2-3].

Наступним пунктом державної підтримки професіонального розвитку вчителів в Австралії є Програма якісного вчителя австралійського уряду (Australian Government Quality Teacher Program, AGQTP), розроблена федеральними урядами. Програма відображає сутність освітніх реформ в Австралії і робить цінний внесок в досягнення мети Національної угоди про партнерство з покращення якості вчителів. Головними цілями Програми є озброєння вчителів навичками і знанням, які необхідні для викладання в 21 столітті; забезпечення національного лідерства в пріоритетних галузях професійного навчання; удосконалення професійної репутації шкільних вчителів і лідерів. Необхідно підкреслити значну роль федеральних урядів в підтримці професійного розвитку вчителя. Так, уряди штатів і територій задля удосконалення якості вчителів запровадили такі ініціативи, як:

1. Програма компетентності в Західній Австралії.

2. Уведення незапатентованих професійних стандартів для вчителів в Квінсленді.

3. Створення Консультативного Комітету при Міністерстві для педагогічного інституту в Вікторії.

4. Рекомендації в доповіді «Якість має значення», Новий Східний Уельс.

5. Програми професійного розвитку в Північній Території.

6. Принципи регістрації вчителів на Території Федеральної Столиці, в Східній 
Австралії й Тасманії.

Як бачимо, зазначені факти свідчать про прагнення австралійського уряду дослідити діапазон інновацій у галузі освіти, професійного навчання й розвитку зокрема. Уряд спрямовує свій потенціал на відповідні підходи до професійного росту, що вже отримали визнання й підтримку і продемонстрували певний вплив на професійну діяльність учителів і учнівську успішність. Мова йде про Глобальні тенденції у професійному навчанні, діяльності й розвитку (Global trends in professional learning and performance and development), що були започатковані AITSL в 2013 році [7, с. 6]. Завдання проекту - дослідження організацій в 10 країнах, включаючи Австрію, Велику Британію, Індію, США, Фінляндію, Японію і т. д., для виявлення, аналізу й перспективного використання інноваційних підходів до професійного розвитку й навчання вчителів. Дослідження виявили п’ять напрямків у професійному навчанні, діяльності й розвитку, які, на думку AITSL, можуть бути використані національними і професійними організаціями у процесі підготовки й розвитку вчителів: інтегрований підхід (integrated approach), імерсивний підхід (immersive approach), проектний підхід (design-led approach), ринковий підхід (market-led approach) і відкритий підхід (open approach).

Дослідження, проведені AITSL, виявили, що професійне навчання без відриву від професійної діяльності $є$ більш ефективним для вдосконалення вчительської практики у школах, ніж багато традиційних зовнішніх можливостей професійного розвитку [6, с. 2]. У зв'язку з цим, різними професійними організаціями Австралії надається активна підтримка професійного розвитку учителів. Серед подібних професійних організацій є Австралійський Союз освіти (Australian Education Union), Австралійський інститут навчання і розвитку, Рада асоціацій професійного навчання у штаті Вікторія. Такі організації, як Австралійська Асоціація природознавців (Australian Science Teachers' Association), Австралійська Асоціація вчителів англійської мови (Australian Association of Teachers of English), Австралійські граматисти (Australian Literacy Educators of Australia) і Австралійська Асоціація вчителів математики (Australian Association of Mathematics Teachers) всі отримали національне фінансування задля розроблення стандартів для конкретної дисципліни для висококваліфікованого фахівця.

Професійні асоціації, як Curriculum Corporation (Товариство з розробки освітньої програми) i ACER (Австралійська Рада 3 наукових досліджень в галузі освіти), забезпечують розробку освітньої програми та інновації на національному рівні. Зокрема, Curriculum Corporation відповідає за розробку освітньої програми для шкіл і систем, створення і поширення високоякісних навчальних матеріалів. Curriculum Corporation видає журнал для вчителів «EQ Australia», який регулярно друкує дослідження австралійських науковців та освітян 3 питань освітньої програми та професійної діяльності вчителів; організує щорічні національні форуми для вчителів і шкільних лідерів задля обговорення важливих питань у галузі педагогіки, навчання i викладання [9, с. 54].

Узагальнюючи матеріал документів з питань освіти і педагогіки, створених державними і професійними організаціями Австралії, можна зробити відповідний висновок про стан запиту і підтримки професійного розвитку вчителів середніх шкіл Австралії. Перш ніж розглядати суспільний запит професійного розвитку вчителів, необхідно надати загальну картину навчального середовища і носія знань, вчителя, зокрема. Соціальний контекст професійного розвитку вчителів середніх шкіл реалізовується, по-перше, через державні вимоги й підтримку вчителів. Підтвердженням цього $є$ низку ініціативних проектів, програм i документів, 
спрямованих на підтримку розвитку якісних учителів в Австралії. По-друге, активна підтримка професійного розвитку вчителів надається різними професійними організаціями Австралії, які орієнтуються не тільки на національні стандарти, вимоги і форми професійного розвитку вчителів, а й на глобальні тенденції у професійному навчанні.

\section{Література}

1. Australian Charter for the Professional Learning of Teachers and School Leaders. AITSL, 2012. - 10 p. 2. Australian Qualifications Framework. - Australian Qualifications Framework Council, 2013. - 112 p. 3. Australian Teacher Performance and Development Framework. - AITSL, 2012. - 14 p. 4. Certification of Highly Accomplished and Lead Teachers in Australia. - AITSL, 2012. - 26 p. 5. Dennis Sparks. Designing powerful professional development for teachers and principals / Sparks Dennis. - Oxford: National Staff Development Council, 2002. - 153 p. 6. Designing Professional Learning. - AITSL, 2014. - 30 p. 7. Global trends in professional learning and performance \& development. Some implications and ideas for the Australian education system. - AITSL, 2014. - 36 p. 8. Katarina Tuinamuana. Teacher Professional Standards, Accountability, and Ideology: Alternative Discourses / Tuinamuana Katarina // Australian Journal of Teacher Education. 2011. - Vol. 36. - № 12. - P. 72-82. 9. National Professional Standards for Teachers. AITSL, 2011. - 24 p. 10. The Senate. Education, Employment and Workplace Relations References Committee. Teaching and learning - Maximising our investment in Australian schools. - Commonwealth of Australia, 2013. - 116 p.

Ілона Сіліванова

\section{ГЕНЕЗА РОЗВИТКУ МІЖНАРОДНОЇ АКАДЕМІЧНОЇ МОБІЛЬНОСТІ В УНІВЕРСИТЕТАХ ФРАНЦЇ̈}

Сіліванова I. М. Генеза розвитку міжнародної академічної мобільності в університетах Франції.

Стаття присвячена проблемі генези та етапів розвитку міжнародної академічної мобільності іноземних студентів в університетах Франції. Метою статті $є$ визначення історичних передумов процесу академічної мобільності та виокремлення i аналіз етапів розвитку. 3'ясовано, що міжнародна академічна мобільність в університетах Франції - це історичне явище, яке набуло популярності одночасно із заснуванням перших європейських університетів.

Ключові слова: міжнародна академічна мобільність, університет, іноземний студент, мобільний студент, міжнародний студент, вхідна мобільність.

Силиванова И. М. Генезис развития международной академической мобильности в университетах Франции.

Статья посвящена проблеме генезиса и этапов развития международной академической мобильности иностранных студентов в университетах Франции. Целью статьи является определение исторических предпосылок академической мобильности, выделение и анализ этапов развития. Выяснено, что международная академическая мобильность в университетах Франции это историческое явление, которое стало популярным с появлением первых европейских университетов.

Ключевые слова: международная академическая мобильность, университет, иностранный студент, мобильный студент, международный студент, входящая мобильность. 